\title{
Effects of a short laying rest on postrest egg production and egg quality
}

\author{
TUOMO KIISKINEN and HILKKA HAKATIE
}

\begin{abstract}
KIISKINEN, T. \& HAKATIE, H. 1993. Effects of a short laying rest on postrest egg production and egg quality. Agric. Sci. Finl. 2: 437-445. (Agric. Res. Centre of Finland, Inst. Animal Prod., FIN-31600 Jokioinen, Finland.)
\end{abstract}

\begin{abstract}
Two factorial trials, each including three commercial laying hybrids, were conducted to study the effects of a short laying rest on postrest performance of hens and on egg quality. A total of 1800 hens laying at $65 \%$ on an average ( 70 wks of age) were subjected to one of the following treatments: no rest (control, C) or feeding only whole-grain barley (WB) or fasting (F, Trial 1 only) until the rate of lay dropped to $0 \%$, after which the birds were returned to the previous all-mash diet. The second laying period was six months.

Egg production of the WB and F hens ceased within one week on an average and the birds were out of production for 10 days. Laying intensity during the second production period did not differ significantly between the treatments in each trial, but egg weight and daily egg mass production increased as a result of the rest treatments. The laying rest procedures reduced feed intake, improved feed efficiency and increased live weight significantly. Egg shell and albumen quality traits were significantly better in the laying rest groups than in the controls. Significant differences in performance and egg quality between the hybrids were mainly ascertained in Trial 2 . The results suggest that a short laying rest is a feasible means of improving egg quality towards the end of the laying period. It can be accomplished successfully by feeding whole-grain barley.
\end{abstract}

Key words: laying hen, short laying rest, egg production, feed efficiency, egg shell quality, egg albumen quality

\section{Introduction}

Most of the forced molting methods involve the use of extended fasting for 10 days or more and withdrawal of water for a couple of days. Nowadays these kinds of treatments are considered to be too drastic and questionable for animal welfare reasons. During a laying period of 14-16 months, egg shell and albumen quality decline rapidly towards the end of the period. Therefore, alternatives for the conventional molting methods have been sought and studied in order to avoid starvation stress while still improving egg quality. The aim of these softer treatments is cessation of lay, after which normal feeding is continued immediately.

Cessation of lay is induced by fasting or by using feeding regimens which cause marked and rapid reduction in feed intake. CHRISTMAS et al. (1985) obtained good results with a short four-day fasting method, which were comparable to those obtained from a 10-day fasting procedure. These authors proposed the term "rest" instead of the term "molt" when a procedure for cessation of lay is used. However, other results suggest that egg shell quality may further be improved using fasting periods of 10 days or longer (KOELKEBECK et al. 1992). One of 
the most studied feeding procedures is applying diets that are excessively supplemented with a trace mineral like zinc, iodine and copper. Birds fed diets containing 10-20 g/kg zinc (SCOTT and CREGER 1976, SHIPPEE et al. 1979, McCORMICK and CUNNINGHAM 1984, ABU-SEREWA and KARUNAJEEWA 1985 ) or $7.5 \mathrm{~g} / \mathrm{kg}$ iodine (SHIRLEY et al. 1979) were found to drastically reduce their feed intake, and the rate of lay dropped to zero within one week. Also low-calcium and low-sodium diets have been tested, but these treatments have not proved to be efficient enough to induce a sudden and total drop in egg production (BLAIR and GILBERT 1973, WHITEHEAD and SHANNON 1974, GILBERT and Blair 1975, NESBETH et al. 1976a,b, Ross and HERRICK 1981, BERRY and BRAKE 1985). Although many of the above procedures may be useful they are not very easy to apply in practice. Additionally, the hen has to excrete or accumulate the extra trace mineral absorbed during the treatment. E.g. extensive accumulation of zinc in organs has been reported (McCORMICK and CUNNINGHAM 1984, 1987). Good results have been obtained by giving only whole-grain barley for one week, which is a procedure very easy to accomplish in practice (ABU-SEREWA and KARUNAJEEWA 1985).

The purpose of the present study was to evaluate the effects of a short laying rest on egg production, feed intake and egg quality during the subsequent laying period, using mainly the whole-grain barley method.

\section{Material and methods}

Two factorial trials were conducted using three commercial laying hybrids in each. The birds in each trial had been used for a previous feeding experiment up to 62 weeks of age, and at the start of the present trials they were 70 weeks old. The hens were housed three to a cage in a 3-tier battery where they remained until 93 weeks of age. Water was given ad libitum and a 16-h daily photoperiod was maintained throughout the experiments.

In Trial 1, three Finnish White Leghorn laying hybrids (SF 1, LSK 61, MÄ 86) were subjected to the following treatments: 1) no rest (control, C), 2) feeding whole-grain barley (WB) until laying ceased or 3) fasting (F) until laying ceased. Two foreign hybrids Lohmann (LSL) and Isabrown (IB) and one Finnish hybrid (MÄ 86) were subjected to treatments 1 or 2 in Trial 2. Mean rate of lay before the rest procedures was $65.7 \%$ (range $64.4-66.4 \%$ among the hybrids) in Trial 1 and $64.5 \%$ (61.5$67.3 \%$ ) in Trial 2. The control groups of each trial were fed a complete layer diet throughout the experiments consisting of six 28 -day periods. The layer diet in Trial 1 was a commercial all-mash diet containing $15.5 \%$ analyzed crude protein (air-dried basis, $\mathrm{CP}$ ) and $10.5 \mathrm{MJ} / \mathrm{kg}$ calculated metabolizable energy (ME). In Trial 2 the all-mash diet was mixed from a commercial concentrate (CP 43\%), barley, oats and limestone. The CP content of this mixture was $16.1 \%$ and $\mathrm{ME}$ content $10.3 \mathrm{MJ} / \mathrm{kg}$. Hens on the laying rest treatments were given the control diet immediately after cessation of lay. In Trial 1, 12 replicates of 30 hens were allocated for each treatment and hybrid. In Trial 2 the treatments had 18 replicates and the hybrids 12 replicates of 20 hens, each. Equal numbers of birds from the treatments of the previous feeding experiment were randomly assigned to the replicates in both trials.

Egg production, feed consumption and mortality were determined for each replicate. Egg production (number and weight) was recorded daily and feed intake for every 4-week period during the second laying period. Twelve and six birds per replicate in Trials 1 and 2, respectively, were weighed before and after the rest procedure and at the end of the postrest laying period. Egg quality traits (Haugh Unit=HU, specific gravity, shell strength, number of blood and meat spots) were determined when the birds were 75 and 93 weeks old. Specific gravity was measured by the saline flotation method (Trial 1) and by the Archimedes' method (Trial 2). A Wazan compression force meter was used for the determination of shell strength $(\mathrm{kg})$ and an Ames $\mathrm{HU}$ micrometer for evaluation of albumen quality (Haugh Unit). Ten eggs from each replicate were randomly collected for each determination. Number of cracked and broken eggs (Trial 2) and total number of shell defects (Trial 2) were recorded for one week during periods 2 and 6. Cracked eggs were detected by candling. The experimental data 
Table 1. Effect of the rest procedures on cessation of lay, feed intake and body weight loss'

\begin{tabular}{|c|c|c|c|}
\hline & \multicolumn{2}{|c|}{ Trial 1} & \multirow{2}{*}{$\begin{array}{c}\text { Trial } 2 \\
\text { WB }\end{array}$} \\
\hline & WB & $\mathrm{F}$ & \\
\hline $\begin{array}{l}\text { Number of days to } \\
\text { zero rate of lay }\end{array}$ & 7 (4-9) & $6(5-7)$ & $6(4-8)$ \\
\hline $\begin{array}{l}\text { Number of days } \\
\text { out of production }\end{array}$ & $10(7-12)$ & $12(10-14)$ & $9(7-12)$ \\
\hline $\begin{array}{l}\text { Barley intake } \\
\text { during treatment } \\
\mathrm{g} / \text { day/bird }\end{array}$ & $39(31-52)$ & - & $19(8-35)$ \\
\hline $\begin{array}{l}\text { Body weight loss } \\
\text { during treatment } \\
\%( \pm S D)\end{array}$ & $11.4 \pm 4.39$ & $17.6 \pm 3.78$ & $19.9 \pm 6.25$ \\
\hline
\end{tabular}

1 Range of replicates in brackets

$\mathrm{WB}=$ whole-grain barley, $\mathrm{F}=$ fast

were statistically analyzed by a generalized multivariate analysis of variance and covariance (MANOVA) using a SPSS-programme. The comparison between the treatments was performed using Tukey's test (STEEL and TORRIE 1960).

\section{Results and discussion}

Hens of the rest treatments in both trials showed a complete interruption of egg production within one week (Table 1). The birds of the WB groups were out of production for 9-10 days and those of the fasted group for 12 days. Daily intake of barley was $39 \mathrm{~g}$ and $19 \mathrm{~g}$ in Trials 1 and 2, respectively. Birds lost $11 \%$ (WB, Trial 1), 18\% (F, Trial 1) and 20\% (WB, Trial 2) of their weight during the treatments. This is markedly less than the $27-31 \%$ recommended by BAKER et al. (1983) for hens molted by a conventional fasting method.

Laying rate of the rest groups recovered quickly after the treatments and reached the level of the control group in period 2 and the highest peak $(72-73 \%)$ in period 3 (Figures 1 and 2). The rested hens were still laying at a higher rate $(60-63 \%)$ than the controls $(51 \%)$ in the last period.

In neither trial did the rest procedures significantly affect the average laying intensity (Tables 2

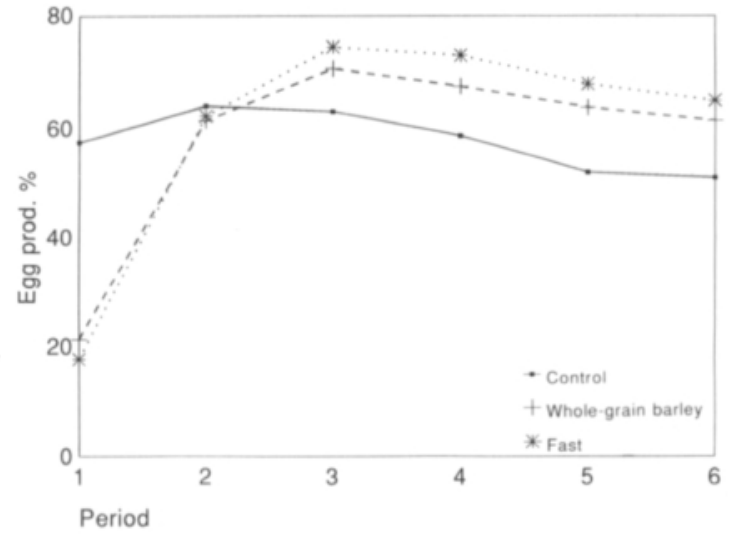

Fig. 1. Percentage egg production during the postrest laying period (Trial 1).

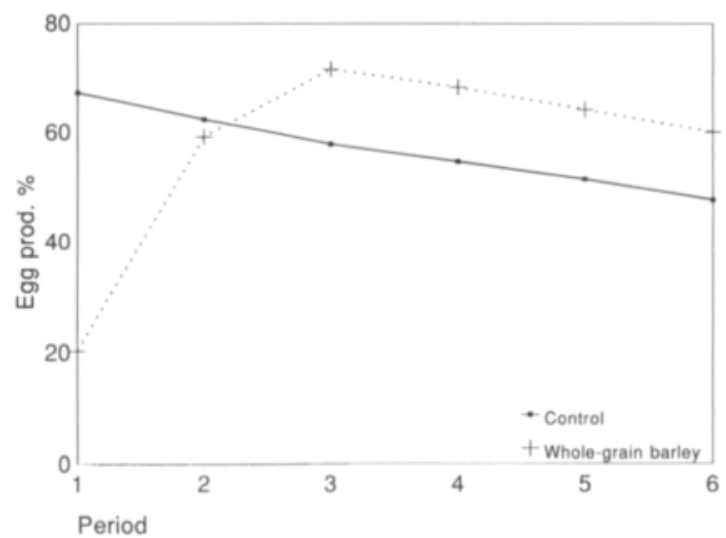

Fig. 2. Percentage egg production during the postrest laying period (Trial 2).

and 3). In Trial 1, the mean rates of hen-day egg production were $57.4 \%$ (C), $57.7 \%$ (WB) and $60.1 \%(\mathrm{~F})$. Rate of lay of the treatment groups in Trial 2 was very similar on an average (57.0/57.1\%). Increased egg weight $(\mathrm{P}<0.05)$ is to be seen as a result of the laying rest in Trial 1 and the response in Trial 2 was even more prominent $(\mathrm{P}<0.05)$. Thus the daily egg mass of the rested groups was 1-2 $\mathrm{g}$ higher than that of the controls, and the difference between the $\mathrm{F}$ and $\mathrm{C}$ groups was found to be significant $(\mathrm{P}<0.05$, Trial 1). Egg production per housed hen was also slightly higher in the rested goups compared with the controls. In 
Table 2. Performance of hens in the second laying period (70-93 wks, Trial 1).

\begin{tabular}{|c|c|c|c|c|c|c|c|c|c|c|}
\hline \multirow{2}{*}{$\begin{array}{l}\text { Treat- } \\
\text { ment } \\
(\mathrm{T})\end{array}$} & \multirow{2}{*}{$\begin{array}{l}\text { Hybrid } \\
(\mathrm{H})\end{array}$} & \multirow{2}{*}{$\begin{array}{l}\text { Rate } \\
\text { of } \\
\text { lay } \%\end{array}$} & \multirow{2}{*}{$\begin{array}{c}\text { Egg } \\
\text { weight } \\
\mathrm{g}\end{array}$} & \multicolumn{2}{|c|}{ Egg output } & \multicolumn{2}{|c|}{ Feed intake } & \multirow{2}{*}{$\begin{array}{c}\text { Final } \\
\text { live } \\
\text { weight } k g\end{array}$} & \multirow{2}{*}{$\begin{array}{c}\text { Weight } \\
\text { gain } \\
\%\end{array}$} & \multirow{2}{*}{$\begin{array}{c}\text { Mortality } \\
\%\end{array}$} \\
\hline & & & & $\begin{array}{c}\text { g/hen/ } \\
\text { day }\end{array}$ & $\begin{array}{c}\mathrm{kg} / \text { housed } \\
\text { hen }\end{array}$ & $\begin{array}{c}\text { g/hen/ } \\
\text { day }\end{array}$ & $\begin{array}{c}\mathrm{kg} / \mathrm{kg} \\
\text { eggs }\end{array}$ & & & \\
\hline \multirow[t]{4}{*}{$\mathrm{C}$} & SF 1 & 54.9 & 66.9 & 36.7 & 6.11 & 120.3 & 3.28 & 1.84 & -2.9 & 15.9 \\
\hline & LSK 61 & 59.7 & 65.5 & 37.9 & 6.31 & 116.4 & 3.08 & 1.85 & 0.8 & 12.5 \\
\hline & MÄ 86 & 57.8 & 65.7 & 39.1 & 6.54 & 119.6 & 3.06 & 1.96 & 1.9 & 7.5 \\
\hline & Mean & 57.4 & 66.1 & $37.9^{\mathrm{a}}$ & $6.32^{a}$ & $118.7^{a}$ & $3.14^{\mathrm{a}}$ & $1.88^{\mathrm{a}}$ & $0.02^{a}$ & $11.9^{\mathrm{a}}$ \\
\hline \multirow[t]{4}{*}{ WB } & SF 1 & 57.8 & 67.0 & 38.9 & 6.51 & 112.6 & 2.92 & 1.93 & 6.0 & 10.0 \\
\hline & LSK 61 & 59.0 & 66.4 & 39.4 & 6.60 & 112.9 & 2.91 & 2.08 & 7.6 & 4.2 \\
\hline & MÄ 86 & 56.4 & 66.7 & 37.8 & 6.34 & 112.7 & 2.87 & 2.11 & 7.3 & 5.0 \\
\hline & Mean & 57.7 & 66.7 & $38.7^{\mathrm{ab}}$ & $6.48^{\mathrm{ab}}$ & $112.7^{b}$ & $2.92^{\mathrm{b}}$ & $2.04^{b}$ & $7.0^{\mathrm{b}}$ & $6.4^{b}$ \\
\hline \multirow[t]{5}{*}{$\mathrm{F}$} & SF 1 & 59.7 & 66.6 & 40.0 & 6.70 & 110.6 & 2.77 & 1.95 & 6.0 & 6.7 \\
\hline & LSK 61 & 58.8 & 66.0 & 39.1 & 6.56 & 113.9 & 2.92 & 2.20 & 10.2 & 5.0 \\
\hline & MÄ 86 & 61.8 & 66.4 & 41.2 & 6.91 & 112.7 & 2.74 & 2.11 & 10.6 & 8.3 \\
\hline & Mean & 60.1 & 66.3 & $40.1^{\mathrm{b}}$ & $6.72^{\mathrm{b}}$ & $112.4^{b}$ & $2.81^{\mathrm{b}}$ & $2.09^{\mathrm{b}}$ & $9.0^{\mathrm{b}}$ & $6.7^{b}$ \\
\hline & SEM & 0.54 & 0.16 & 0.35 & 0.060 & 0.62 & 0.033 & 0.014 & 0.51 & 0.98 \\
\hline \multicolumn{11}{|c|}{ Significance of F-value } \\
\hline & $\mathrm{T}$ & NS & $*$ & $*$ & $*$ & $* * *$ & $* * *$ & $* * *$ & $* * *$ & \\
\hline & $\mathrm{H}$ & NS & NS & NS & NS & NS & NS & $* * *$ & $* *$ & \\
\hline & $\mathrm{T} \times \mathrm{H}$ & NS & NS & NS & NS & $*$ & $*$ & $*$ & NS & \\
\hline
\end{tabular}

$a-b \quad$ Treatment means with no common superscript letter are significantly different $(\mathrm{P}<0.05)$.

If no letters are used the differences are non-significant.

$\mathrm{SEM}=$ standard error of mean. Significances: $\mathrm{NS}=$ non-significant, ${ }^{*}=\mathrm{P}<0.05,{ }^{* *}=\mathrm{P}<0.01,{ }^{* * *}=\mathrm{P}<0.001$

$\mathrm{C}=$ control, $\mathrm{WB}=$ whole-grain barley, $\mathrm{F}=$ fast

Trial 1 this was partly due to reduced $(\mathrm{P}<0.05)$ mortality among the rested hens. In Trial 2 mortality was not affected by the laying rest. No significant differences between the rest procedures were found in the production parameters (Trial 1).

The results of earlier studies obtained either with a short fast (CHRISTMAS et al. 1985, KOELKEBECK et al. 1992) or by feeding whole-grain barley (ABUSEREWA and KARUNAJEEWA 1985) show that these methods have a tendency to improve egg yield during the second laying period. These observations are confirmed by the results of the present study.

Birds subjected to the rest procedures, with the rest period included, consumed significantly $(\mathrm{P}<0,001)$ less feed and utilized feed more efficiently than the control birds in each trial (Tables 2 and 3). The decreases in feed conversion ratio $(\mathrm{FCR})$ were $7-10 \%(\mathrm{P}<0.001$, Trial 1$)$ and $7 \%$
$(\mathrm{P}<0.01$, Trial 2). Significant differences in feed consumption were not ascertained between the resting methods (Trial 1). Earlier reports do not support the decreased daily feed intake found in this study. However, the results of CHRISTMAS et al. (1985) and ABU-SEREWA and KARUNAJEEWA (1985) showed a lower FCR for the short rest groups (short fast, whole-grain barley) than for the controls. A considerable difference in feed consumption was found between the trials. This was partly due to the different hen material and the different ME value of the diets. The commercial diet of Trial 1 contained more ME $(10.5 \mathrm{MJ} / \mathrm{kg})$ than the farm-mixed diet of Trial $2(10.3 \mathrm{MJ} / \mathrm{kg})$ since the commercial diet contained wheat and more added fat.

The rested hens were significantly heavier at the end of the trials and gained relatively more weight during the experiments than the control birds (Tables 2 and 3). This appears contradictory since 
Table 3. Performance of hens in the second laying period (70-93 wks. Trial 2).

\begin{tabular}{|c|c|c|c|c|c|c|c|c|c|c|}
\hline \multirow{2}{*}{$\begin{array}{l}\text { Treat- } \\
\text { ment } \\
(\mathrm{T})\end{array}$} & \multirow{2}{*}{$\begin{array}{l}\text { Hybrid } \\
\text { (H) }\end{array}$} & \multirow{2}{*}{$\begin{array}{l}\text { Rate } \\
\text { of } \\
\text { lay } \%\end{array}$} & \multirow{2}{*}{$\begin{array}{c}\text { Egg } \\
\text { weight } \\
\text { g }\end{array}$} & \multicolumn{2}{|c|}{ Egg output } & \multicolumn{2}{|c|}{ Feed intake } & \multirow{2}{*}{$\begin{array}{c}\text { Final } \\
\text { live } \\
\text { weight kg }\end{array}$} & \multirow{2}{*}{$\begin{array}{c}\text { Weight } \\
\text { gain } \\
\%\end{array}$} & \multirow{2}{*}{$\begin{array}{c}\text { Mortality } \\
\%\end{array}$} \\
\hline & & & & $\begin{array}{c}\mathrm{g} / \mathrm{hen} / \\
\text { day }\end{array}$ & $\begin{array}{l}\mathrm{kg} / \text { housed } \\
\text { hen }\end{array}$ & $\begin{array}{l}\mathrm{g} / \mathrm{hen} / \\
\text { day }\end{array}$ & $\begin{array}{l}\mathrm{kg} / \mathrm{kg} \\
\mathrm{eggs}\end{array}$ & & & \\
\hline \multirow[t]{4}{*}{$\mathrm{C}$} & MÄ 86 & 58.1 & 67.9 & 39.5 & 6.61 & 132.9 & 3.38 & 2.09 & 3.9 & 0.8 \\
\hline & LSL & 61.7 & 68.7 & 42.4 & 7.08 & 143.1 & 3.38 & 1.94 & 5.1 & 7.5 \\
\hline & IB & 51.1 & 70.3 & 35.8 & 5.98 & 138.8 & 3.89 & 2.30 & 2.1 & 5.0 \\
\hline & Mean & 57.0 & 69.0 & 39.2 & 6.56 & 138.2 & 3.55 & 2.09 & 3.7 & 4.4 \\
\hline \multirow[t]{5}{*}{ WB } & MÄ 86 & 58.1 & 68.8 & 40.0 & 6.70 & 124.6 & 3.15 & 2.09 & 12.1 & 5.0 \\
\hline & LSL & 61.8 & 70.2 & 43.4 & 7.28 & 134.1 & 3.11 & 2.03 & 8.4 & 5.8 \\
\hline & IB & 51.4 & 71.8 & 36.8 & 6.19 & 132.8 & 3.61 & 2.47 & 10.8 & 7.5 \\
\hline & Mean & 57.1 & 70.3 & 40.1 & 6.72 & 130.5 & 3.29 & 2.19 & 10.4 & 6.1 \\
\hline & SEM & 1.04 & 0.27 & 0.67 & 0.11 & 1.24 & 0.06 & 0.024 & 0.63 & 1.01 \\
\hline \multicolumn{11}{|c|}{ Significance of F-value } \\
\hline & $\mathrm{T}$ & NS & $* * *$ & NS & NS & $* * *$ & $* *$ & $*$ & $* * *$ & NS \\
\hline & $\mathrm{H}$ & $* * *$ & $* * *$ & $* * *$ & $* * *$ & $* * *$ & $* * *$ & $* * *$ & NS & NS \\
\hline & $\mathrm{T} \times \mathrm{H}$ & NS & NS & NS & NS & NS & NS & NS & NS & NS \\
\hline
\end{tabular}

Significances: NS $=$ non-significant, ${ }^{*}=\mathrm{P}<0.05,{ }^{* *}=\mathrm{P}<0.01,{ }^{* * *}=\mathrm{P}<0.001$

$\mathrm{C}=$ control, $\mathrm{WB}=$ whole-grain barley, $\mathrm{F}=$ fast

the rested birds had consumed less feed and utilized it better than the control ones.

Significant differences were not ascertained for production or feed intake between the Finnish hybrids in Trial 1 (Table 2). In the previous feeding experiment, the egg weight of SF 1 was on an average $1.2 \mathrm{~g}$ lower $(\mathrm{P}<0.001)$ and the FCR $2.4 \%$ higher $(\mathrm{P}<0.05)$ than of the other hybrids (KIISKINEN unpubl.). On the other hand, significant $(\mathrm{P}<0.001)$ differences were found in each production and feed intake parameter in Trial 2 (Table 3). In hen-day production, both LSL and MÄ 86 were significantly better than IB. IB hens produced the heaviest $(70.3 \mathrm{~g})$ and $\mathrm{MÄ} 86$ the lightest eggs $(68.3 \mathrm{~g})$. Both LSL and IB consumed more feed than MÄ 86. MÄ 86 was as efficient as LSL in feed conversion and both were significantly better than IB. The results of the previous feeding experiment (KIISKINEN unpubl.) and a test conducted during the 14 months' laying period (PÄRKÖ and STOLT 1993) confirmed similar differences between these hybrids. Only very few treatment $x$ hybrid interactions $(\mathrm{P}<0.05)$ were found, and these were in Trial 1 (Table 2).
Throughout the experiments, the average Haugh Unit values of eggs laid by the rested hens were significantly higher than of eggs laid by the control birds (Tables 4 and 5). Even at the end of the postrest laying period the differences in $\mathrm{HU}$ were 5-6 units. No significant differences were found between the rest methods (Trial 1). ABU-SEREWA and KARUNAJEEWA (1985) observed that the HU of eggs laid by the rested hens was higher than of eggs laid by the control group. STEVENSON and JACKSON (1984) used excess zinc and copper to induce a molt which significantly improved the $\mathrm{HU}$ after molting.

Specific gravity and shell strength values of the eggs reflected a significant improvement in shell quality obtained with each resting method (Tables 4 and 5). No significant differences in egg quality traits were found between the two methods (Trial 1). These results are in agreement with the results of earlier short rest studies (ABU-SEREWA and KARUNAJEEWA 1985, Christmas et al. 1985, KOELKEBECK et al. 1992). The percentage of cracked eggs did not differ significantly between the treatments in each trial. The proportion of cracked eggs, especially in Trial 1, was clearly 
Table 4. Egg quality traits in the second laying period (Trial 1).

\begin{tabular}{|c|c|c|c|c|c|c|c|c|c|}
\hline \multirow{2}{*}{$\begin{array}{l}\text { Treatment } \\
\text { (T) }\end{array}$} & \multirow{2}{*}{$\begin{array}{l}\text { Hybrid } \\
\text { (H) }\end{array}$} & \multicolumn{4}{|c|}{ 1st determination (75 wks) } & \multicolumn{4}{|c|}{ 2nd determination (93 wks) } \\
\hline & & $\mathrm{HU}$ & $\begin{array}{l}\text { Spec. } \\
\text { gravity }\end{array}$ & $\begin{array}{c}\text { Shell } \\
\text { strength }\end{array}$ & $\begin{array}{c}\text { Cracked } \\
\text { eggs } \%\end{array}$ & $\mathrm{HU}$ & $\begin{array}{l}\text { Spec. } \\
\text { gravity }\end{array}$ & $\begin{array}{c}\text { Shell } \\
\text { strength }\end{array}$ & $\begin{array}{c}\text { Cracked } \\
\text { eggs } \%\end{array}$ \\
\hline \multirow[t]{4}{*}{$\mathrm{C}$} & SF 1 & 74.6 & 1.0768 & 2.50 & 6.4 & 70.7 & 1.0767 & 2.42 & 16.5 \\
\hline & LSK 61 & 74.0 & 1.0785 & 2.50 & 7.4 & 68.8 & 1.0748 & 2.34 & 13.1 \\
\hline & MÄ 86 & 74.1 & 1.0789 & 2.54 & 6.3 & 69.9 & 1.0753 & 2.50 & 11.6 \\
\hline & Mean & $74.2^{\mathrm{a}}$ & $1.0781^{\mathrm{a}}$ & $2.51^{\mathrm{a}}$ & 6.7 & $69.8^{\mathrm{a}}$ & $1.0756^{\mathrm{a}}$ & $2.42^{a}$ & 13.7 \\
\hline \multirow[t]{4}{*}{ WB } & SF 1 & 81.8 & 1.0819 & 2.82 & 3.7 & 77.9 & 1.0785 & 2.61 & 10.8 \\
\hline & LSK 61 & 77.9 & 1.0831 & 3.04 & 2.6 & 74.0 & 1.0776 & 2.59 & 7.9 \\
\hline & MÄ 86 & 79.8 & 1.0826 & 3.03 & 3.3 & 77.9 & 1.0775 & 2.64 & 9.9 \\
\hline & Mean & $79.8^{\mathrm{b}}$ & $1.0825^{b}$ & $2.96^{b}$ & 3.2 & $76.6^{b}$ & $1.0779^{b}$ & $2.61^{b}$ & 9.5 \\
\hline \multirow[t]{5}{*}{$\mathrm{F}$} & SF 1 & 82.9 & 1.0813 & 2.91 & 2.2 & 76.7 & 1.0781 & 2.67 & 7.9 \\
\hline & LSK 61 & 77.1 & 1.0823 & 2.97 & 3.6 & 76.0 & 1.0771 & 2.71 & 8.1 \\
\hline & MÄ 86 & 81.6 & 1.0839 & 3.12 & 2.1 & 74.9 & 1.0771 & 2.59 & 10.8 \\
\hline & Mean & $80.5^{b}$ & $1.0825^{b}$ & $3.00^{\mathrm{b}}$ & 2.6 & $75.8^{b}$ & $1.0774^{\mathrm{b}}$ & $2.65^{b}$ & 8.9 \\
\hline & SEM & 0.50 & 0.00028 & 0.035 & 0.28 & 0.55 & 0.00029 & 0.033 & 0.52 \\
\hline \multicolumn{10}{|c|}{ Significance of F-value } \\
\hline & $\mathrm{T}$ & $* * *$ & $* * *$ & $* * *$ & NS & $* * *$ & $* *$ & $* *$ & NS \\
\hline & $\mathrm{H}$ & $*$ & $*$ & NS & NS & NS & NS & NS & NS \\
\hline & $\mathrm{T} \times \mathrm{H}$ & NS & NS & NS & NS & NS & NS & NS & NS \\
\hline
\end{tabular}

a-b See Table 2 .

Significances: $\mathrm{NS}=$ non-significant, ${ }^{*}=\mathrm{P}<0.05,{ }^{* *}=\mathrm{P}<0.01,{ }^{* * *}=\mathrm{P}<0.001$

$\mathrm{C}=$ control, $\mathrm{WB}=$ whole-grain barley, $\mathrm{F}=$ fast

Table 5. Egg quality traits in the second laying period (Trial 2).

\begin{tabular}{|c|c|c|c|c|c|c|c|c|c|}
\hline \multirow{2}{*}{$\begin{array}{l}\text { Treatment } \\
\text { (T) }\end{array}$} & \multirow{2}{*}{$\begin{array}{l}\text { Hybrid } \\
\text { (H) }\end{array}$} & \multicolumn{4}{|c|}{ 1st determination (75 wks) } & \multicolumn{4}{|c|}{ 2nd determination ( $93 \mathrm{wks}$ ) } \\
\hline & & $\mathrm{HU}$ & $\begin{array}{l}\text { Spec. } \\
\text { gravity }\end{array}$ & $\begin{array}{c}\text { Shell } \\
\text { strength }\end{array}$ & $\begin{array}{l}\text { Cracked } \\
\text { eggs } \%\end{array}$ & $\mathrm{HU}$ & $\begin{array}{l}\text { Spec. } \\
\text { gravity }\end{array}$ & $\begin{array}{c}\text { Shell } \\
\text { strength }\end{array}$ & $\begin{array}{c}\text { Cracked } \\
\text { eggs } \%\end{array}$ \\
\hline \multirow[t]{4}{*}{$\mathrm{C}$} & MÄ 86 & 72.3 & 1.0776 & 2.55 & 8.1 & 72.5 & 1.0715 & 2.36 & 6.7 \\
\hline & LSL & 68.6 & 1.0821 & 2.44 & 2.8 & 68.2 & 1.0769 & 2.38 & 5.0 \\
\hline & IB & 64.1 & 1.0846 & 2.70 & 5.3 & 63.2 & 1.0807 & 2.47 & 11.1 \\
\hline & Mean & 68.3 & 1.0814 & 2.56 & 5.4 & 68.0 & 1.0763 & 2.40 & 7.6 \\
\hline \multirow[t]{5}{*}{ WB } & MÄ 86 & 78.3 & 1.0803 & 2.76 & 2.8 & 78.7 & 1.0753 & 2.65 & 7.5 \\
\hline & LSL & 78.2 & 1.0848 & 3.08 & 3.8 & 76.9 & 1.0793 & 2.60 & 7.5 \\
\hline & IB & 67.5 & 1.0865 & 2.81 & 5.6 & 61.6 & 1.0804 & 2.79 & 6.7 \\
\hline & Mean & 74.7 & 1.0839 & 2.88 & 4.1 & 72.4 & 1.0783 & 2.68 & 7.2 \\
\hline & SEM & 0.78 & 0.00057 & 0.046 & 0.62 & 0.88 & 0.00062 & 0.043 & 0.66 \\
\hline \multicolumn{10}{|c|}{ Significance of F-value } \\
\hline & $\mathrm{T}$ & $* * *$ & $*$ & $* * *$ & NS & $* *$ & NS & $* *$ & NS \\
\hline & $\mathrm{H}$ & $* * *$ & $* * *$ & NS & NS & $* * *$ & $* * *$ & NS & NS \\
\hline & $\mathrm{T} \times \mathrm{H}$ & NS & NS & $*$ & NS & $*$ & NS & NS & NS \\
\hline
\end{tabular}

Significances: NS $=$ non-significant, ${ }^{*}=\mathrm{P}<0.05,{ }^{* *}=\mathrm{P}<0.01,{ }^{* * *}=\mathrm{P}<0.001$

$\mathrm{C}=$ control, $\mathrm{WB}=$ whole-grain barley, $\mathrm{F}=$ fast 
Table 6. Other egg quality traits in the second laying period (Trial 2).

\begin{tabular}{|c|c|c|c|c|c|c|c|c|c|c|c|c|}
\hline & \multicolumn{4}{|c|}{ Control } & \multicolumn{4}{|c|}{ Whole-grain barley } & \multirow[b]{2}{*}{ SEM } & \multicolumn{3}{|c|}{ Signific. of $F$} \\
\hline & MÄ 86 & LSL & IB & Mean & Mă 86 & LSL & IB & Mean & & $\mathrm{T}$ & $\mathrm{H}$ & $\mathrm{T} \times \mathrm{H}$ \\
\hline \multicolumn{13}{|l|}{ 1st determination } \\
\hline Blood spots $\%$ & 3.3 & 6.7 & 3.3 & 4.4 & 1.7 & 1.7 & 0 & 1.1 & 0.87 & NS & NS & NS \\
\hline Meat spots $\%$ & 0 & 1.7 & 28.3 & 10.0 & 3.3 & 0 & 41.7 & 15.0 & 1.75 & NS & $* * *$ & NS \\
\hline Broken eggs $\%$ & 11.6 & 12.3 & 14.6 & 12.8 & 5.9 & 3.3 & 12.1 & 7.1 & 1.02 & $* *$ & $*$ & NS \\
\hline Shell defects $\%$ & 20.3 & 16.6 & 20.2 & 19.0 & 9.0 & 7.3 & 17.8 & 11.3 & 1.27 & $* *$ & $*$ & NS \\
\hline \multicolumn{13}{|c|}{ Percentage in fresh egg } \\
\hline Albumen $\%$ & 60.9 & 60.2 & 61.8 & 61.0 & 61.0 & 61.6 & 61.9 & 61.5 & 0.13 & $*$ & $* *$ & NS \\
\hline Yolk $\%$ & 29.2 & 29.1 & 27.4 & 28.6 & 28.5 & 27.5 & 27.3 & 27.7 & 0.13 & $* * *$ & $* * *$ & $*$ \\
\hline Shell $\%$ & 9.9 & 10.7 & 10.8 & 10.4 & 10.5 & 10.9 & 10.8 & 10.8 & 0.05 & $* *$ & $* * *$ & $*$ \\
\hline \multicolumn{13}{|l|}{ 2nd determination } \\
\hline Blood spots \% & 5.0 & 5.0 & 0 & 3.3 & 1.7 & 3.3 & 0 & 1.7 & 0.82 & NS & NS & NS \\
\hline Meat spots $\%$ & 0 & 0 & 45.0 & 15.0 & 1.7 & 0 & 41.7 & 14.4 & 1.87 & NS & $* * *$ & NS \\
\hline Broken eggs $\%$ & 17.9 & 13.1 & 18.6 & 16.5 & 9.8 & 9.2 & 15.3 & 11.4 & 1.46 & NS & NS & NS \\
\hline Shell defects $\%$ & 25.9 & 19.4 & 29.7 & 25.0 & 17.6 & 16.9 & 23.6 & 19.4 & 1.50 & $*$ & NS & NS \\
\hline \multicolumn{13}{|c|}{ Percentage in fresh egg } \\
\hline Albumen $\%$ & 61.1 & 60.6 & 62.2 & 61.3 & 60.8 & 61.2 & 61.8 & 61.3 & 0.14 & NS & $* *$ & NS \\
\hline Yolk $\%$ & 29.1 & 29.0 & 27.3 & 28.5 & 29.3 & 28.2 & 28.0 & 28.5 & 0.13 & NS & $* * *$ & $*$ \\
\hline Shell $\%$ & 9.8 & 10.4 & 10.5 & 10.2 & 9.9 & 10.6 & 10.2 & 10.2 & 0.06 & NS & $* * *$ & NS \\
\hline
\end{tabular}

Significances: $\mathrm{NS}=$ non-significant, ${ }^{*}=\mathrm{P}<0.05,{ }^{* *}=\mathrm{P}<0.01,{ }^{* * *}=\mathrm{P}<0.001$

$\mathrm{T}=$ treatment, $\mathrm{H}=$ hybrid

lower in the rested groups than in the control group, and this is uniform with the determined shell quality traits.

The positive effects of the rest methods on shell quality were also confirmed by the percentage of broken eggs in Trial 2 (Table 6). The difference between the control and the WB group was significant $(\mathrm{P}<0.01)$ in the first determination. The WB method significantly decreased the total percentage of eggs with defective shell. This could be ascertained in each determination. On the other hand, the WB treatment did not significantly affect the incidence of blood and meat spots, although, the presence of blood spots was less frequent in eggs laid by the WB hens than in eggs laid by the control hens. The WB procedure resulted in a significant increase in the proportions of albumen and shell of fresh eggs and decrease in the proportion of yolk at the beginning of the postrest laying period (1st determination) (Table 6). At the end of the production period, the compositions of the eggs were similar in both treatment groups in Trial 2.
Also in egg quality traits, only few significant $(\mathrm{P}<0.05)$ differences between the hybrids were found in Trial 1 (Table 4). These occurred in the $\mathrm{HU}$ and specific gravity of the first determination. During the previous feeding experiment, eggs laid by $M \ddot{A} 86$ hens were found to have a better $(\mathrm{P}<0.01)$ albumen quality $(\mathrm{HU})$ than those laid by SF 1 and LSK 61 (KIISKINEN unpubl.). In Trial 2, significant $(\mathrm{P}<0.001)$ differences between the hybrids were observed for $\mathrm{HU}$ and specific gravity in each determination (Table 5). In eggs laid by IB hens, albumen was markedly more watery than in eggs laid by the other hybrids. This is a typical phenomenon which has also been ascertained in other connections (KIISKINEN unpubl., PÄRKÖ and STOLT 1993). It appears that, as a whole, the HU did not change appreciably during the postrest laying period in Trial 2. Only the rested IB hens laid eggs with a decreased $\mathrm{HU}$ at the end of the experiment. There was an interaction $(\mathrm{P}<0.05)$ between treatment and hybrid for $\mathrm{HU}$ in the second determination, with the $\mathrm{HU}$ of the WB group among the IB 
hens being even lower than that of the control. The differences in specific gravity were rather clear, MÄ 86 having the lowest values, IB the highest and LSL in between. Similar results were obtained in the previous feeding experiment (KIISKINEN unpubl.) and in a control station test (PÄRKÖ and STOLT 1993). The shell strength values of the hybrids were not quite uniform with the values of specific gravity, and significant differences were not observed between the hydrids. Also the incidences of broken and defective shells on the whole did not correspond to the values of specific gravity among the hybrids, since eggs laid by the IB hens had had the highest specific gravity but also the highest incidence of broken and defective eggs, and differed significantly from the values of LSL. These observations suggest that shell thickness does not fully explain shell strength. In addition to $\mathrm{HU}$ values, eggs laid by the IB hens differed markedly $(\mathrm{P}<0.001)$ from the other hybrids in the incidence of meat spots (Table 6). The percentage of eggs with meat spots was $39 \%$ on an average in the
IB groups but only $1 \%$ in the MÄ 86 and LSL groups.

Significant differences between the hybrids (Trial 2) occurred in the percentages of all egg components (Table 6). The proportion of albumen was higher and that of yolk lower in eggs laid by IB hens compared with eggs laid by the other hybrids. Eggs laid by MÄ 86 hens contained the least proportion of shell, and this result is consistent with the specific gravity values. Significant $(\mathrm{P}<0.05)$ interactions were found between treatment and hybrid for the proportion of yolk in each determination and for the proportion of shell in the first determination.

The results of the present study lead to the conclusion that a short laying rest is a useful and feasible method for improving egg quality during the last third of the production period, because it also improves feed efficiency and may increase egg yield. The study indicates that feeding whole-grain barley until laying ceases is a successful way of accomplishing the rest.

\section{References}

Abu-Serewa, S. \& Karunajeewa, H. 1985. A comparison of methods for rehabilitating aging hens. Aust. J. Exp. Agric. 25: 320-325.

BAKER, M., BraKe, J. \& McDANIEL, G.R. 1983. The relationship between body weight loss during an induced molt and post molt egg production, egg weight and shell quality in caged layers. Poult. Sci. 62: 409-413.

BERRY, W.D. \& BRAKE, J. 1985. Comparisons of parameters associated with molt induced by fasting, zinc and low dietary sodium in caged layers. Poult. Sci. 64: 20272036.

Blair, R. \& GILBERT, A. 1973. The influence of supplemental phosphorus in a low-calcium diet designed to induce a resting phase in laying hens. Brit. Poult. Sci. 14: 131-135.

Christmas, R.B., Harns, R.H. \& Junqueira, O.M. 1985. Performance of single White Leghorn hens subjected to 4 or 10-day feed withdrawal force rest procedures. Poult. Sci. 64: 2321-2324.

GilberT, A. \& BlaIR, R. 1975. A comparison of the effects of two low-calcium diets on egg production in the domestic fowl. Brit. Poult. Sci. 16: 547-552.

Koelkebeck, K.W., Parsons, C.M., Leeper, R.W. \& Moshtaghian, J. 1992. Effect of duration of fasting on postmolt laying hen performance. Poult. Sci. 71: 434439.

McCormick, C.C. \& Cunningham, D.L. 1984. High dietary zinc and fasting as methods of forced resting: A performance comparison. Poult. Sci. 63: 1201-1206.

— \& Cunningham, D.L. 1987. Performance and physiological profiles of high dietary zinc and fasting as methods of inducing a forced rest: A direct comparison. Poult. Sci. 66: 1007-1013.

Nesbeth, W.G., Douglas, C.R. \& Harms, R.H. 1976a. Response of laying hens to a low salt diet. Poult. Sci. 55: 2128-2132.

-, Douglas, C.R. \& Harms, R.H. 1976b. The potential use of dietary salt deficiency for the force resting of laying hens. Poult. Sci. 55: 2375-2380.

PÄrkō, J. \& SтоLт, J. 1993. Urjalan kanatalouskoeaseman tulokset 1991-1993. Siipikarja 75: 106-112.

Ross, E. \& HerRick, R.B. 1981. Forced rest induced by molt or low salt diet and subsequent hen performance. Poult. Sci. 60: 63-67.

Scott, J.T. \& Creger, C.R. 1976. The use of zinc as an effective molting agent in laying hens. Poult. Sci. 55: 2089 (Abstract.).

Shippee, R.L., Stake, P.E., Koehn, U., Lambert, J.L. \& Simmons, R.W. 1979. High dietary zinc or magnesium as forced-resting agents for laying hens. Poult. Sci. 58: 949 954.

Shirley, H., Tugwell, R. \& McGhee, G. 1979. The effects of induced pauses on the performance of layers. Tenne- 
see Farm and Home Sci. 12: 19-21. (Ref. Abu-Serewa, S. \& Karunajeewa, H. 1985.)

SteEl, R.S.D. \& TorrIE, J.H. 1960. Principles and Procedures of Statistics. 81 p. New York.

Stevenson, M.H. \& JACKson, N. 1984. Comparison of dietary hydrated copper sulphate, dietary zinc oxide and a direct method for inducing a moult in laying hens. Brit. Poult. Sci. 25: 505-517.

Whitehead, C.C. \& Shannon, D.W.F. 1974. The control of egg production using a sodium-deficient diet. $\mathrm{Br}$. Poult. Sci. 15: 429-434.
Manuscript received June 1993

Tuomo Kiiskinen

Hilkka Hakatie

Agricultural Research Centre of Finland

Institute of Animal Production

FIN-31600 Jokioinen, Finland

\title{
SELOSTUS
}

\section{Lyhyen munintalevon vaikutus munantuotantoon ja munan laatuun}

\author{
TUOMO KIISKINEN ja HILKKA HAKATIE
}

Maatalouden tutkimuskeskus

Tutkimuksessa selvitettiin lyhyen munintalevon käyttökelpoisuutta lähinnả munan laatuongelmien vähentämisessä munintakauden viimeisen kolmanneksen aikana. Kahdessa kokeessa oli kaikkiaan 1800 kanaa, jotka kokeiden alkaessa olivat munineet 11 kk (ikä 70 vk) muninnan ollessa keskimäärin $65 \%$. Kummassakin kokeessa oli 3 hybridiä, ensimmäisessä kokeessa pelkästään kotimaisia (SF 1, LSK 61, MÄ 86) ja toisessa kokeessa tämän hetken tärkein kana-aineksemme MÄ 86, LSL (Lohmann) ja IB (Isabrown), joista kaksi viimeksimainittua ovat ulkomaisia hybridejä. Munintalepo toteutettiin ensimmäisessä kokeessa syöttämällä kanoille ainoastaan ohranjyviă tai paastottamalla niitä kunnes muninta lakkasi. Tämän jälkeen kanat saivat vapaasti normaalia täysrehua, jota vertailuryhmä sai koko ajan. Toisessa kokeessa olivat mukana vertailuryhmä ja ohranjyväryhmä. Molemmat kokeet kestivăt kuusi neljän viikon jaksoa.

Munintaleporyhmien tuotanto laski keskimäärin viikon kuluessa nollaan pysyen siină keskimäärin 10 päivăä. Ohranjyviä kului kanaa kohden päivăssä 39 (Koe 1) ja $19 \mathrm{~g}$ (Koe 2). Levon jälkeen kanojen muninta elpyi nopeasti saavuttaen vertailuryhmän tason toisella jaksolla ja huippunsa (72-73\%) kolmannella jaksolla. Kokonaisuudessaan munintalepo ei vaikuttanut munintaprosenttiin, mutta lisäsi munanpainoa, mistä syystä päivittäiset grammatuotokset ja alkanutta kanaa kohden lasketut kilotuotokset olivat levänneillä ryhmillä vertailuryhmiä suuremmat. Viimeksi mainittuun vaikutti myös leporyhmien alentunut kuolleisuus kokeessa 1. Leporyhmien kanat söivät merkitsevästi vähemmän ja kuluttivat rehua $7-10 \%$ vähemmän munakiloa kohden kuin vertailuryhmä.

Munintalevon ansiosta munan laatu parani merkittävästi. Valkuaisen kiinteyttä kuvaava Haugh-luku oli leporyhmien munissa kokeiden lopussakin 5-6 yksikköä korkeampi kuin vertailuryhmien munissa. Myös kuoren laatu (ominaispaino, kestävyys) oli leporyhmillä sekä kokeiden alussa että lopussa vertailuryhmää selvästi parempi. Toisessa kokeessa havaittiin lisäksi rikkonaisten ja kuorivirheellisten munien määrän vähentymistä munintaleporyhmissä.

Tutkimus osoitti, että lyhyt munintalepo on käyttökelpoinen keino munan laadun parantamiseen munintakauden lopulla. Se voidaan toteuttaa helposti syöttämällä noin viikon ajan vain ohranjyviä. 